\title{
POVO DE DEUS E POVO DE ROMA: LIMITES E RELAÇÕES ENTRE DOIS UNIVERSALISMOS
}

\author{
POPOLO DI DIO E POPOLO DI ROMA: LIMITI E RELAZIONI DI DUE \\ UNIVERSALISMI
}

\author{
Valerio Neri ${ }^{1}$ \\ Tradução
}

Andréa Rosin Caprino Taborda ${ }^{2}$

Os impérios universais são instituições criadas pelo poder político para a sua exaltação. A ideia de universalismo é baseada no desconhecimento do alcance dos seus limites territoriais e da sua hegemonia, além de uma simplificação ideológica do verdadeiro contexto em que o poder político se encontra. Possuímos respaldo para tal afirmação ao observarmos a tradição imperial do Antigo Oriente descrita no livro de Daniel, como o reino dos assírios, dos medos, dos persas e de Alexandre, o Grande, até os impérios universais da Idade Moderna, como o de Carlos V e de Luís XIV (BOSBACH, 1998). Os impérios orientais tinham uma porção limitada do continente asiático; Alexandre conquistou a Pérsia e agregou a ela a Grécia e a Macedônia em território ocidental. Consequentemente, ficou conhecido como um conquistador universal, tendo suas investidas interrompidas pelo cansaço do exército e pela morte prematura.

\footnotetext{
${ }^{1}$ Valerio Lieto Salvatore Neri é professor doutor aposentado, porém ainda atuante junto à Università di Bologna, Itália. A sua pesquisa versa sobre a história romana tardo-antiga, com especial atenção aos aspectos político, social e cultural. Texto originalmente publicado em "Confini, circolazione, identità ed ecumenismo nel mondo antico". Atti del VII Incontro di Studi tra storici e giuristi dell'Antichità, Vercelli, 24-25 maggio 2018. Serie diretta da Arnaldo Marcone. Milano: Mondadori Education, 2020.

${ }^{2}$ Doutoranda em História pela UFPR, com período sanduíche na Universidade de Bolonha, Itália (2019), mestre em História pela UFPR (2017) e graduada em História-Licenciatura e Bacharelado pela mesma instituição (2014). E-mail: andreiarosincaprino@gmail.com
} 
Políbio imputava aos romanos, em meados do século II a.C., a quase total hegemonia sobre o território (POLÍBIO, I, 69, 3; Ver BARONOWSKI, 2011; MUSTI, 1978, 13-39) - porém em uma perspectiva restrita ao mundo helenístico. Mais tarde, a progressão da extensão do Império e a afirmação da sua contínua expansão ${ }^{3}$ tornou cada vez mais justificada a crença no destino universal do Império Romano, que encontraria o seu ápice na Era de Augusto. Também o cristianismo, em outra esfera, exprime uma ideologia universalista cuja plena realização se projeta em um futuro que coincide com o fim dos tempos, quando o advento do reino de Deus sucederia à pregação do Evangelho a todos os povos. A perspectiva universalista cristã não tende à conquista espiritual de todos os povos e a uma conversão universal, mas apenas à pregação universal realizada no futuro, no final da história. Já o Império Romano proclama a sua extensão universal a partir do Império de Augusto. Para ambos, a afirmação ideológica não corresponde à realidade - pelo menos não totalmente. Mesmo com um breve conhecimento geográfico da extensão territorial, essa discrepância é evidente, especialmente porque o Oriente foi em grande parte ocupado após a desintegração do reino selêucida por uma formação imperial - o reino parto - que infligiu duras derrotas aos romanos no último século republicano - aos exércitos de Crasso e Antônio ${ }^{4}$. Geógrafos da época de Augusto, como Estrabão, apontam essa discrepância em detalhes, embora observem que os romanos possuíam a melhor e mais famosa parte do mundo. Os romanos tinham toda a Europa sob seu controle, exceto as terras de além do Danúbio e aquelas ao longo do Oceano entre o Reno e o Tánais. Possuíam a faixa costeira da África, menos o interior, no qual existiam apenas nômades; diferentemente, a parte mais oriental da Ásia era ocupada por uma série de povos, tais como os partos, os indianos, os bactrianos, os citas, os árabes e os etiópios (ESTRABON, VI 4, 2). Essa situação apontava para uma diferença impossível de ignorar entre os romanos e o Império com o qual eles

\footnotetext{
${ }^{3}$ Cícero afirma que o elogio epigráfico dos grandes generais se sustenta na ampliação do domínio romano (rep. III 24: unde enim esset illa laus in summorum imperatorum incisa monumentis 'finis imperii propagavit', nisi aliquid de alieno accessisset).

${ }^{4}$ Para o conhecimento dos territórios para além das fronteiras do Império conferir: Slooties -. Peachin 2016; Chiai 2015; Wells 2013.
} 
se confrontavam continuamente, aquele criado pelo conquistador do Império persa, Alexandre, o Grande. Tal obstáculo à afirmação de um Império Romano universal poderia ser contornado, dada a improbabilidade de conquista da Pérsia, da construção e reivindicação de uma superioridade reconhecida pelo Império inimigo, como no caso da restituição das insígnias romanas levadas aos exércitos de Crasso e Antônio sob Augusto, e a coroação do rei da Armênia, Tirídates, por Nero ou, de uma forma mais geral, com a acentuação do carácter bárbaro do inimigo iraniano (HARTMANN, 2008; LEROUGE, 2011; LEROUGE, 2007). Esta contribuição destina-se a tratar, sobretudo na época referente à Antiguidade Tardia, da evolução da relação entre as duas ideologias universalistas e da consciência dos seus reais limites espaciais.

No início do Império, a ideologia universalista de Augusto, a qual enraizava-se na cultura política dos últimos séculos da República, principalmente nos ideais políticos dos césares $^{5}$, se sustentava pelo reconhecimento da relação com os territórios e os povos de além dos limites imperiais, o que evidenciava, para além da questão do domínio territorial, uma gama de relações de dependência desses povos em relação ao Império Romano, a qual se manifestava tanto na sua condição de clientes ou vassalos quanto no reconhecimento da superioridade do Império, além da homenagem diplomática e amizade que lhe eram oferecidas.

No prefácio das Res gestae de Augusto, provavelmente endereçado a Tibério, afirma-se que o governante sujeitou o mundo ao domínio do povo romano. Dessa forma, diferentemente de como havia feito Alexandre - em

\footnotetext{
5 Os cipiões em particular são representados como herdeiros do Império macedônio e por Políbio, especialmente, como patronos do mundo, cfr. Bianchetti 2012. Na representação de Lívio, a guerra contra Antíoco III é apresentada como uma guerra com a qual os romanos aspiravam ao domínio universal. O rei sírio escreve a Prusa da Bitínia que os romanos passaram pela Ásia para destruir todos os reinos (XXXVII 25, 4: venire eos ad omnia regna tollenda ut nullum usquam orbis terrarum nisi Romanum imperium esset). Também em Lívio, Tibério Graco afirma que Lúcio Cipião imperium populi Romani propagaverit in ultimos terrarum fnes (XXXVIII 60, 4). Uma primeira afirmação no âmbito romano da identificação do domínio romano com o orbis romanus é encontrada na época. De Sula, como evidencia Vogt 1960, na Rhetorica ad Herennium IV, 9, 13, falando dos socii itálicos rebeldes na guerra social: nedum illi imperium orbis terrae, cui imperio omnes gentes, reges, nationes partim vi partim voluntate consenserunt, cum aut armis aut liberalitate a populo Romano superati essent, ad se transferre tantulis viribus conarentur. Em Cícero, a esfera mundial do Império Romano, como também a esfera mundial da política e da legislação romana, são continuamente afirmadas.
} 
quem Antônio, o rival de Augusto, inspirou-se -, a conquista e a hegemonia empreendidas pelo primeiro imperador romano não teriam sido realizadas com intenções pessoais. Claude Nicolet observa que tal reputação corresponde completamente ao conteúdo do documento em cuja esfera das ações de Augusto está o espaço territorial ${ }^{6}$; é descrito um mundo em que todos os povos e governos reconhecem, ou são forçados a reconhecer, a hegemonia romana. Os partos restituíram as insígnias capturadas aos exércitos de Crasso e de Antônio ${ }^{7}$ e o rei Fraates IV confiou-lhes filhos e netos como reféns ${ }^{8}$. Embaixadores foram enviados por reis indianos (WHITTAKER, 2000) e bastarnas, citas, sármatas, o reino albanês, ibéricos e medos propuseram aliança. A conquista do espaço geográfico não foi resultado apenas do domínio territorial em si, mas teve sucesso em grande medida porque governos de naturezas diversas reconheceram a hegemonia romana e buscaram firmar um pacto com o Império, além de constatarem a sua superioridade militar.

Esse ideal teve longo desenvolvimento no pensamento de Augusto. Um fragmento de Tito Lívio atribui ao imperador em 24 a.C., no seu retorno da Britânia, a afirmação pública da convergência da atividade militar e diplomática ao conquistar o mundo ${ }^{9}$. Fora do domínio territorial direto e independentemente dos projetos expansionistas, como a conquista e a provincialização da Germânia, à qual Augusto renuncia depois da derrota de Teutoburgo (mas as Res gestae falam de uma Germânia pacificada até Elba), e de uma guerra contra os partos - que ele parece nunca ter levado em consideração, em

\footnotetext{
${ }^{6}$ R. Gest. Div. Aug. 3: Bella terra et mari civilia externaque toto orbe terrarum saepe gessi. Cfr. Nicolet 1991.

${ }^{7}$ R. Gest. Div. Aug. 29: Parthos trium exercitum Romanorum spolia et signa reddere mihi supplicesque amicitiam populi Romani petere coegi.

8 Augusto habilmente transforma em uma vitória ideológica, quase um gesto de submissão do rei parto, apresentado como forçado a retornar, o que presumivelmente foi o resultado de um trato e talvez implicado da parte romana o pagamento de um resgate (Cfr. GaslainMaleuvre2006). A entrega de filhos e netos como reféns também é apresentada como um gesto de submissão, embora não tenha havido uma derrota militar (R. Gest. Div. Aug. 32: Ad me rex Parthorum Phrates Orodis filius filios suos nepotesque omnes misit in Italiam non bello superatus, sed amicitiam nostram per liberorum suorum pignora petens). Como bem aponta Wiesenhofer 2010, considera em plano de igualdade com o Império o reino parto e evidencia a sua alteridade cultural.

${ }^{9}$ Liv. fr. 55: Caesar Augustus in spectaculis Romano populo nuntiat regressus a Britannia insula totum orbem terrarum tam bello quam amicitiis Romano imperio subditum.
} 
contraste com César (SOMMER, 2010), o imperador ofereceu um quadro amplo e articulado da hegemonia romana para além dos limites do Império, que poderia justificar em grande parte a sua pretensão de ofertar ao povo romano um Império universal, celebrado pela literatura contemporânea ${ }^{10}$. Entre os governos dos quais se tinha algum conhecimento, talvez falte apenas o Império chinês, com o qual existiam relações comerciais há muito tempo, especialmente o comércio da seda. Entretanto, o conhecimento sobre o ambiente geográfico e político chinês era muito limitado, e as relações diplomáticas com essa nação parecem não ter existido.

A justificação do caráter universal do Império Romano que Augusto apresenta nas Res gestae é ao mesmo tempo mais refinada e realista do que a de Dionísio de Halicarnasso em suas Antiguidades romanas, cujas inexatidões grosseiras são refutadas. Dionísio relaciona o universalismo imperial romano somente com a conquista em si e afirma que os romanos estenderam o seu domínio sobre todas as terras que não eram inacessíveis ou desabitadas - mas os governos que nas Res gestae têm relações diplomáticas com o Império não são evidentemente territórios despovoados e inacessíveis! (DIONYSII HALICARNASSENSIS, I 3,3). Às lacunas do domínio universal destacadas por Estrabão, na passagem acima mencionada, parece ser dada uma resposta nas Res gestae, que ao menos atenua a estranheza dessas regiões e povos ao domínio e à hegemonia romana. Estrabão afirmou que na Europa o domínio romano não se estendia à costa do Oceano, desde o Reno até ao Tanai.

Augusto defende que as frotas romanas navegaram da foz do Reno para o Oriente até o território dos cimbros e que esse e outros povos germânicos haviam requerido a amizade romana (RES GESTAE DIUI AUGUSTI, 26). Também o Tanais (atualmente o rio Don), indicado por Estrabão como o limite dos territórios europeus fora do domínio romano, é lembrado por Augusto a propósito dos sármatas, que vivam perto desse rio e enviaram embaixadores aos romanos (RES GESTAE DIUI AUGUSTI, 31). Ainda assim, também na

\footnotetext{
${ }^{10}$ Sobre a ideologia universalista de Augusto, cfr. J.-M. Roddaz 2004; Mehl 1994; Cresci Marrone 1993; Pavan 1989.
} 
Europa, Estrabão disse que as terras para além do Danúbio não pertenciam aos romanos; Augusto, ao contrário, escreve que um exército romano atacou os dácios do outro lado do Danúbio e os fez se submeterem ${ }^{11}$. Etíopes e árabes, cuja independência do domínio romano Estrabão havia destacado, sofreram muitas incursões em seu território por parte dos exércitos de Augusto, conforme o relato das Res gestae ${ }^{12}$. Os partos, como vimos, segundo a mesma obra, restituíram as insígnias capturadas a Antônio e Crasso e quiseram aliar-se ao povo romano; indianos e citas enviaram embaixadores. De maneira geral, praticamente todos os territórios que Estrabão indicou como não pertencentes ao domínio romano, aparecem nas Res gestae de forma oposta, ao reconhecerem a supremacia romana imposta pelas iniciativas militares ou diplomáticas.

Se essa discrepância entre a narrativa de Estrabão e a das Res gestae parece evidente, não é possível indicar os seus meios no estado das nossas fontes. Ampliando o conceito de domínio universal para todas as formas em que a superioridade da potência romana é reconhecida, desde a imposição de dinastias filoromanas até embaixadas que dispuseram-se a firmar aliança, Augusto pode demonstrar que o domínio romano coincidia de fato, pelo menos em grande parte, com o mundo conhecido pelos geógrafos, afastando-se, pois, dos intelectuais gregos contemporâneos, como Dionísio de Halicarnasso e Estrabão, mas também se distanciando dos projetos de dominação universal celebrados pelos intelectuais do seu tempo que sonhavam com grandes triunfos sobre os povos do Oriente.

\footnotetext{
${ }^{11}$ R. Gest. div. Aug. 30: Citr[a] quod [D]a[cor]u[m tra]n[s]gressus exercitus meis a[u]sp[icis vict] us profligatusque [es]t, et pos[tea tran]s Dan[u]vium ductus ex[ercitus me]u[s] Dacorum gentis im[peri]a p[opuli] R[omani perferre coegit.

${ }^{12}$ R. Gest. div. Aug.26: Meo iussu et auspicio ducti sunt [duo] exercitus eodem fere tempore in Aethiopiam et in Ar[a]biam, quae appel[latur Eudaemon, [maxim]aeque hos[t]ium gentis utr[iu]sque cop[iae] caesae sunt in acie et [c]om[plur]a oppida capta. In Aethiopiam usque ad oppidum Nabata pervent[um]est, cui proxima est Meroe. In Arabiam usque in fines Sabaeorum pro[cess] it exercitus ad oppidum Mariba.
} 
Horácio fala das vitórias futuras sobe os partos, indianos e $\operatorname{seres}^{13}$. Propércio, igualmente, defende triunfos futuros sobre os partos e indianos ${ }^{14}$. Pode-se pensar que tais expectativas de triunfo e conquista estivessem mais próximas a uma primeira fase do universalismo de Augusto, quando o imperador contemplava o projeto de redução da Germânia à província, e que as Res gestae representariam uma fase mais madura da sua abordagem ao tema, cujos valores não foram marginalizados, mas adequados à realidade de acordo com ideais que, como vimos, o governante havia elaborado anteriormente. No final do seu governo Augusto não podia deixar de reconhecer que esses triunfos não haviam ocorrido, mas que, de alguma forma, essas regiões haviam entrado na esfera romana. O imperialismo universalista de Augusto encontra uma correspondência magnífica no grande mapa mundial feito por Agripa no pórtico de Vipsânia, em Roma, no qual é mostrado ao público romano uma representação visível do domínio universal romano, na variedade de formas das quais falamos (ARNAUD, 2007-2008).

Mais tarde, diante de uma continuidade notória no caráter universalista do imperador, especialmente na titulação das inscrições gregas, ${ }^{15}$, como nas expressões de louvor presentes na literatura, nos epigramas de $\operatorname{Marcial}^{16}$, por exemplo, ou nas Silvae de Estácio ${ }^{17}$, como também nos símbolos figurativos de poder universal, como o globo associado à figura do imperador, mesmo nos períodos de renúncia à expansão territorial ou de contração do domínio romano, não possuímos documentos que analisam a colocação em âmbito mundial do Império Romano análoga às Res gestae. Além disso, não podemos afirmar se a concepção de Augusto do universalismo imperial romano como hegemonia

\footnotetext{
${ }^{13}$ Hor. carm. I 12, 53-57: ille seu Parthos Latio imminentis/egerit iusto domitos triumpho/sive subiectos Orientis orae/Seras et Indos; carm. III 5, 3-4: praesens divus habebitur Augustus/adiectis Britannisimperio gravibusque Persis.

${ }^{14}$ Prop. III 4, 1: arma deus Caesar dives meditatur ad Indos/et freta gemmiferi fndere classe maris/magna, Quiris, merces: parat ultima terra triumphos/Tigris et Euphrates sub tua iura fluent/sera, sed Ausoniis veniet provincia virgis/assuescent Latio Partha tropaea Iovi.

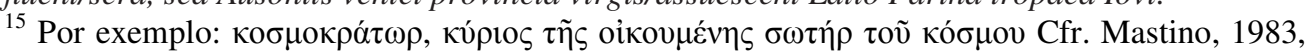
147 ss.

${ }^{16}$ Mart., epigr. VII, 7, 5: te, summe mundi rector et parens orbis: (de Domiciano).

${ }^{17}$ Stat., silv. IV, 2, v. 14: tene ego, regnator terrarum orbisque subacti (também a respeito de Domiciano)
} 
mundial foi partilhada pelos seus sucessores, ou se, mais simplesmente, a extensão efetiva do Império justificou a pretensão de um domínio amplo, como escreve Fílon de Alexandria na obra Legatio ad Gaium (PHIL., 10) ${ }^{18}$.

Um fio condutor que percorre toda a ideologia universalista romana, e principalmente o projeto ou o sonho de uma guerra vitoriosa contra o Império parta e depois o persa, desde a época republicana até o período da Antiguidade Tardia, é a imitação de Alexandre e o desejo de seguir os seus passos (KÜHNEN, 2008). Certamente não é tarefa simples imitar o modelo de Alexandre na empreitada de conquistar os reinos parta e persa, mas a escolha de iniciar uma guerra gerou resultados gratificantes em termos de propaganda, tanto para o imperador quanto para a afirmação da superioridade do Império Romano. Nero, de acordo com Suetônio, intencionava enviar uma expedição aos portões do Cáspio, seguindo o itinerário de Alexandre (PRONTERA, 2012), recrutando para esse fim uma legião que nomeou como "falange de Alexandre" (CASSIUS DIO, LXVIII 30, 1). Também Trajano, durante a sua expedição parta, cumpriu uma série de gestos que lembravam explicitamente o modelo de Alexandre, com finalidade propagandística. Trajano foi para a Babilônia, segundo Dião Cássio, onde ofereceu sacrifícios em honra de Alexandre (CASSIUS DIO, LXVIII 29, 1). Vendo um navio ir em direção à Índia, exclama que, se fosse ainda jovem, teria ele também navegado até lá (CASSIUS DIO, LXVIII 29, 1). Dião Cássio afirma que o imperador relatou ao Senado ter avançado para além dos limites de Alexandre, ainda que o historiador observe que Trajano não conservou os territórios ocupados. O modelo alexandrino inspira a expedição parta empreendida por Caracala em 215, o qual é apresentado como um profundo admirador de Alexandre, inclusive no aspecto físico (HERODIANUS, IV 8, 1). Herodiano narra que o imperador havia proposto ao rei persa de se casar com a filha para unir os dois impérios, ambicionando ao título de Parthicus para anunciar aos romanos que havia submetido todos os bárbaros orientais (HERODIANUS, IV 10, 1-3). O

\footnotetext{
${ }^{18}$ Fílon afirma que a maior parte do mundo pode certamente ser definida tout court ecumene

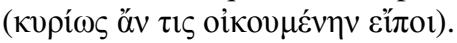


ideal do império universal era, pois, presente no pensamento de Caracala, fosse a nível de propaganda - com a exaltação de uma eventual vitória sobre os partos, fosse a nível real, com o projeto audacioso e improvável de unificar os dois impérios através de um matrimônio.

É feita alusão a Alexandre também na expedição persa concluída, infelizmente, por Juliano. Amiano Marcelino apresenta um discurso que o seu herói teria realizado no início da expedição persa, em que o imperador manifesta a intenção de destruir o império rival ${ }^{19}$, inserindo-a na tradição romana de guerras contra as potências oponentes desde Fidene até Cartago, e aparentemente ignorando o modelo de Alexandre, o Grande, na iniciativa de uma representação coerente e romanizada de Juliano, às custas das suas características helenísticas. A empreitada que Juliano anuncia na passagem de Amiano não é exposta como uma iniciativa individual, como a de Alexandre, mas como uma ação firmemente inserida no quadro do imperialismo "defensivo" romano. Posteriormente Juliano lamenta que a oposição da sua comitiva fez com que o projeto de conquista da Pérsia falisse ${ }^{20}$.

Contudo, para além dos projetos e expectativas racionais, não é absurdo pensar que em algumas expedições contra o reino iraniano pairava, além da finalidade meramente propagandística, o sonho de uma eliminação definitiva do império rival. Essas afirmações concedidas a Juliano contrastam com a falta de preparo evidente demonstrada na renúncia do cerco a Ctesifonte e com o plano de permanecer em Tarso. O projeto de expansão sobre a Pérsia, que é também o de grandes imperadores, suscita as críticas de Dião Cássio, para quem a conquista de territórios pertencentes ao Império persa obtiveram resultados discutíveis (CASSIUS DIO, LXVIII 33; LXXV 3; Conferir BRUNT, 1990). Todavia, as expedições romanas contra o reino iraniano, assim como as persas contra o Império Romano, nunca tiveram a intenção de um confronto definitivo entre os dois Impérios, como ocorreu com a expedição de Alexandre. Apontam, quando muito, à solução da questão armênia, para impor sujeição a governantes

\footnotetext{
${ }^{19}$ abolenda nobis natio molestissima Amm. XXIII, 5, 19.

${ }^{20}$ iam parta regna Persidis Amm. XXIV 7, 1.
} 
que oscilavam entre uma clientela romana e uma persa, como os de Adiabena do Osroena, ou da Ibéria, visando à conquista ou reconquista das províncias mesopotâmicas, mas não a uma vitória definitiva sobre o Império oponente, ainda que no discurso essa vitória fosse sugerida.

Do ponto de vista estratégico, essas expedições servem para manter as duas potências em recíproca dependência e, do ponto de vista propagandístico, a fama de vitória contra o reino iraniano, como Parthicus, Persicus, possui uma função importante no prestígio e na legitimação de um imperador e serve para afirmar a inferioridade do império rival em relação às pretensões universalistas do Império Romano, segundo uma linha que, como vimos, existia já na ideologia de Augusto. No arco de Galério em Tessalônica, que comemora a sua vitória sobre o rei persa Narsete, a liga persa que pediu a paz é apresentada de forma depreciativa. Naturalmente tal gênero de propaganda é exclusiva ao Império. Nas relações diplomáticas entre os dois impérios, na medida em que possuímos documentação, há uma atitude de respeito recíproco sem ostentação de superioridade (MCDONOUGH, 2011).

Nas trocas epistolares entre Sapor II e Constâncio II, de acordo com Amiano, o primeiro reivindica a restituição dos territórios mesopotâmicos e armênios conquistados por Galério, como partes historicamente integrantes do reino persa, para embasar uma paz longa entre os dois governos. Constâncio responde não poder atender ao pedido porque a sua majestade seria lesada, principalmente em um momento em que, derrotados os tiranos, todo o mundo romano lhe obedecia (AMMIANUS, XVII 5, 3-14). Império Romano e Império Persa são apresentados como duas instituições que devem conviver buscando o equilíbrio mútuo.

$\mathrm{Na}$ titulação imperial depois de Trajano (CIL VI, 958; 40501) praticamente desaparece o motivo da dinâmica expansionista territorial do Império - com exceção do seu regresso ocorrido na época dos $\operatorname{Severos}^{21}$ - e,

\footnotetext{
${ }^{21}$ Cfr. a inscrição romana do Senado e do povo dedicada aos três imperadores (o nome de Geta foi corroído) em 202/203 (CIL VI 1033=ILS 425): İmp(eratori) Caes(ari) Lucio Septimio M(arci) fil(io) Severo Pio Pertinaci Aug(usto) patri patriae Parthico Arabico et Parthico Adiabenico, pontific(i) maximo, tribunic(ia) potest(ate) $\overline{X I}$, imp(eratori) $\overline{X I}$, co(n)s(uli) $\overline{I I I}$,
} 
portanto, do progresso efetivo do domínio universal com a nomenclatura de "propagador do território". Tácito apresenta a designação como um dever imperial, assim como havia sido título de mérito dos imperadores republicanos, criticando Tibério por ser negligente nesse quesito (TACITUS, IV 32, 3). Por outro lado, Adriano rejeita explicitamente uma continuidade na tendência expansionista do Império, e nomeia como seu sucessor um velho senador sem qualquer experiência militar, Antonino Pio.

Intelectuais como Apiano aprovam essa política, sustentando que talvez Roma possua as melhores partes das terras e mares, além de não haver razão para continuar a conquistar terras bárbaras que não possam fornecer proveito (APPIANUS, praefatio 7; Conferir BRUNT, 1990, 476). O motivo da propagação do Império, entretanto, é retomado pelos tetrarcas e por quase todos os imperadores do século IV. Trajano é uma figura imperial na qual imperadores do século IV, como Constantino e Teodósio, se inspiram. O governante é representado por Eutrópio como o imperador que mais se aproximou do ideal de domínio universal - é de fato o único que, após Augusto, estendeu os limites do Império $^{22}$-, não apenas enumerando as suas conquistas, mas elencando os povos que se submeteram a ele e relembrando como ele chegou até aos limites do território, alcançando a Índia e o Mar Vermelho (EUTROPIUS, VIII 3, 2).

Os motivos para a expansão romana são retomados em propagandas como, por exemplo, uma inscrição de Palmira, na qual os tetrarcas são celebrados como propagadores do gênero humano. Também Maximiano é honrado em uma inscrição romana com o título de "propagador do império dos romanos" (CIL VI, 36947), e Diocleciano, em uma inscrição siríaca como

proco(n)s(uli) et İmp(eratori) Caes(ari) M(arco) Aurelio L(uci) fil(io) Antonino Aug(usto) Pio Felici, tribunic(ia) potest(ate) $\overline{V I}, c o(n) s(u l i), \operatorname{proco}(n) s(u l i), \quad\langle(p($ atri) p(atriae)》, 《optimis fortissimisque principibus》 5 ob rem publicam restitutam imperiumque populi Romani propagatum insignibus virtutibus eorum domi forisque s(enatus) p(opulus)q(ue) $R$ (omanus). Cfr. também a inscrição da África proconsular IRT, 395. Apenas a Caracala foi dedicada uma inscrição romana em que ele é celebrado como orbis terrarum propagator...providens imperii sui maiestatem finesque eius ampliavit (CIL VI, 1080).

${ }^{22}$ Eutr. VIII 2, 2: Romani imperii, quod post Augustum defensum magis fuerat quam nobiliter ampliatum, fines longe late que diffudit. 
"conservador e propagador do mundo e império dos romanos" (AEP, 2006, 1586). Constantino é louvado em uma inscrição romana como "propagador do império e da autoridade dos romanos e fundador da segurança eterna" (CIL VI, 1140 = ILS 692), e Constâncio é celebrado apenas em uma inscrição romana como "propagador do império dos romanos" (CIL VI, 31395; CIL VI, 1161; AEP, 2010, 1699). Como sempre, o usurpador gálico Maxêncio é homenageado em Roma como "propagador do mundo e da causa romana" $\left(\mathrm{CIL}\right.$ VI, $1166^{\mathrm{a}}=$ ILS, 741; CIL VI, 1167), Juliano é homenageado em uma inscrição de Pérgamo como "propagador da liberdade e das coisas públicas" (CIL III, 7088), Valentiniano e o seu irmão Valente são celebrados em uma inscrição pisana como "promotores do mundo romano e das coisas públicas" (CIL XI, $6664=$ ILS 5824; Para Valentiniano: CIL IX, 661), e Teodósio é elogiado em uma inscrição de Canosa, cuja "virtude, felicidade e justiça é propagada por toda a terra" (CIL IX, 333; AEP 1968, 602).

A diferença entre a celebração da propagação do Império nas inscrições concernentes à Antiguidade Tardia e nas inscrições de Trajano e dos Severos é que nessas o título de "propagador" é acompanhado por epítetos virtuosos. A expansão do Império é apontada explicitamente em relação à vitória contra os seus inimigos. Entretanto, nas inscrições tardo-antigas essa relação é implícita, dada a difusão da celebração, que é típica do século IV a partir de Constantino (GREGORI - FILIPPINI, 2013), (com alguns exemplos também no século V), do carisma do imperador vitorioso e triunfante: o imperador "propagador" é assim chamado apenas quando vence os seus inimigos externos. É significativo de sua inserção na tradição ideológica imperial que o motivo da vitória e da propagação do Império seja retomada pelo rei ostrogodo Teodorico (CIL X, 6850 e 6851; Conferir GIARDINA, 2006, 75-79).

No século III, a referência à universalidade do Império aparece principalmente de maneira defensiva em títulos como "conservador", "defensor", "pacificador do mundo" (MASTINO, 1983, 96-102), e não poderia ser vista de forma diferente, dada a agressividade nos confrontos imperiais com grandes coalizões germânicas, como os godos, os francos e os alamanos, e a 
renovada empreitada imperialista do reino persa sob a dinastia sassânida. Sapor I acrescenta ao título real persa a expressão "rei dos reis do Irã e do não Irã", deixando transparecer uma pretensão universalista que poderia colocá-lo em direta competição com a do Império Romano (HUYSE, 2006, 181-201; BORM, 2008, 426-427).

$\mathrm{Na}$ literatura da primeira idade imperial aparecem definições restritivas do domínio romano. Plínio, o Velho define o território submetido ao domínio de Roma como "nosso mundo", distinguindo-o de outros territórios, como a Índia, a China, a Etiópia, a Arábia, a Pérsia e a Cítia, os quais não faziam parte do espaço e da cultura romana (PLINIUS, VIII, 223; XII, 6; XXIV, 89; XXII, 118 etc). Em Lucano encontramos pela primeira vez a nomenclatura "mundo romano" para indicar o território dominado pelos romanos, "o mundo dos romanos" (LUCANUS, VIII 211) ${ }^{23}$. Encontramos expressões semelhantes na historiografia grega, em Dião Cássio, por exemplo ${ }^{24}$. Contudo, antes do período dos Tetrarcas, não havia nos títulos imperiais expressões similares, a não ser em algumas referências esporádicas ao "seu mundo" de imperadores do século III, como Aureliano e Tácito (CIL VIII, 22474; CIL VIII, 10374).

Na Antiguidade Tardia, por outro lado, tanto nos títulos imperiais das inscrições quanto nos documentos provenientes das próprias chancelarias imperiais, estão presentes expressões da dimensão universal do Império Romano e expressões das fronteiras do domínio romano em relação ao espaço territorial. O soberano é honrado nesse momento, também no Ocidente, como "senhor de todo o mundo" (na parte oriental o soberano era honrado como

\footnotetext{
${ }^{23} \mathrm{Na}$ obra, Lucano apresenta duas opiniões aparentemente divergentes sobre o universalismo do Império. No proêmio dedicado a Nero, Roma é colocada no centro de um Império mundial cuja conquista será completada logo, enquanto depois a descrição da batalha de Farsalo no livro VII, o mundo é dividido em uma parte ocidental e uma oriental, e Roma é o centro do Ocidente. $\mathrm{Na}$ realidade, o otimismo acerca do Império universal expresso em relação a Nero pode manifestar uma homenagem cortesã à capacidade do imperador de retomar completamente o projeto universalista de Augusto. Lembre-se da ênfase dada pelo imperador na coroação em Roma de Tiríades I, rei da Armênia. Eutrópio, falando sobre a guerra civil entre César e Pompeu, afirma que os exércitos que se enfrentaram naquela guerra poderiam facilmente ter conquistado todo o mundo (Eutr. VI, 21, 1: Numquam adhuc Romanae copiae in unum neque maiores neque melioribus ducibus convenerant, totum terrarum orbem facile subacturae, si contra barbaros ducerentur). Cfr. R. Pogorzelski, Orbis Romanus: Lucan and the limits of the Roman world, Transactions of the American Philological Association, 141 (2011), 143-170.

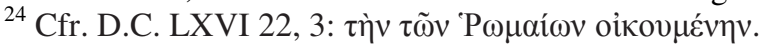


"senhor" (MASTINO, 153-154), ou melhor, "senhor do universo" (IVI 148150) desde o século II). São reverenciados Diocleciano, Constâncio Cloro, Maxêncio, Constantino, Constâncio II, Valentiniano e Valente (IVI 133-134). O imperador é definido em uma constituição de Justiniano como "quem trabalha arduamente dia e noite para o mundo inteiro". Porém, em contextos parecidos, encontramos presentes definições limitantes do domínio romano, como "nosso mundo" ou "mundo romano". Nas inscrições tardo-antigas aparece frequentemente esse gênero de expressões em relação ao conceito de amplificação do domínio ou de liberação do mundo romano. Por exemplo, em uma inscrição de Útica, Constantino é honrado como "provedor e amplificador de todo o mundo romano", o usurpador Magnêncio, assim como o seu adversário Constâncio II, e depois Juliano, são honrados como "libertadores do mundo romano". Em expressões que aludem à "amplificação" ou à "propagação" do Império, contudo, pode-se ler a exaltação de um dinamismo expansivo que, partindo do mundo romano, tende a um domínio universal.

Nas constituições imperiais dos séculos IV-V, no que permanece após o trabalho de redação, a extensão de uma medida e do poder imperial que a emana são representados tanto em relação à órbita terrestre, quanto à parte do mundo sujeita ao domínio romano. É relativamente rara nos séculos IV-V a afirmação da universalidade de uma decisão com referência à órbita terrestre, apesar da evidência de sua aplicação apenas ao território do Império. Por exemplo, em uma constituição de Teodósio de 389, é decretada a expulsão dos maniqueus de toda a terra (CODEX THEODOSIANUS, 16, 5, 1); em uma constituição de Constantino proclama-se a imunidade dos pequenos navios pelo território de todos os que não atendem a sua função específica e (CODEX THEODOSIANUS, 13, 5, 5), em uma constituição de Valentiniano, os anúncios de bem-estar imperial são apresentados como fatos por toda a terra (CODEX THEODOSIANUS, 8, 11, 3). Em uma Novela ${ }^{25}$ de Teodósio II, as províncias imperiais e o espaço terrestre, as terras e todas as províncias são

25 "Novela" é um gênero literário que se constitui em uma narrativa breve, geralmente em prosa, que trata de fatos verídicos ou ficcionais. Neste caso, trata-se de uma lei imperial promulgada após a publicação do Código de Teodósio II em 438. (N.T.) 
mencionadas de forma redundante como a área geográfica em que a lei deveria ser aplicada (THEODOSIUS, 20, 2).

Nesse período há também a alusão ao "mundo romano" ou ao "nosso mundo". Em uma constituição de Honório de 415, o confisco dos bens de templos diz respeito a "cada região do nosso mundo" (CODEX THEODOSIANUS, 16, 10, 20), enquanto em uma Novela de Valentiniano III, ordena-se que a constituição imperial se faça conhecida em "todos os lugares do nosso mundo" (VALENTINIANUS, 25, 10). Uma constituição de Valente de 367 advertiu que nenhuma região do espaço romano deveria ser negligenciada na busca dos metaleiros fugitivos (CODEX THEODOSIANUS, 10, 9, 5). Na constituição de Justiniano, quando se faz referência à órbita terrestre, há a especificação de que se trata da parte territorial sob o domínio romano, em expressões como "em toda a esfera terrestre em que há o domínio romano" (C. 2, 58, 2pr), "em todo o espaço territorial regido por nossos governantes" (C. 3, 1, 14). Com relativa frequência nas constituições de Justiniano se fala do "mundo romano" ou "nosso mundo" (C.1, 3, 53, 2; 6, 23, 31, 1; 9, 13, 1). Por outro lado, várias constituições indicam o espaço territorial como o âmbito no qual a lei deve ser aplicada. Em uma constituição de 530, a expressão "espaço terrestre" é relacionada claramente com a difusão da lei em todos os lugares e épocas, sem aspecto restritivo (C. 3.1. 13). Da mesma forma, uma constituição de 531 enfatiza com a expressão "órbita terrestre" a aplicação a todo o Império de um edito: "com esse edito colocamos em prática a lei na órbita terrestre" (C. $6,23,29)$. Na constituição que segue a citada de 530, um pouco posterior, os funcionários em questão são designados como os de Constantinopla e do resto do Império, que é definido como "a órbita terrestre em que os nossos governantes reinam”. Assim, em curtos intervalos de tempo, são elaboradas expressões diferentes por parte da chancelaria imperial para enfatizar a extensão das leis. Nessas expressões, há alusões sutis à ideologia universalista. 
$\mathrm{Na}$ literatura panegirística ${ }^{26}$, nos panegíricos latinos dos tetrarcas até Teodósio, que obviamente é próxima à ideologia do imperador honrado, o poder imperial é frequentemente apontado como relativo a toda a órbita terrestre, e as vitórias imperiais, como relativas a toda a terra (PANEGYRICUS, X 2, 1; XI 19, 4). Assim, a literatura está em consonância com os títulos imperiais presentes na epigrafia. No entanto, em alguns casos, aparecem definições limitantes no âmbito do poder e da ação do imperador. Por exemplo, no panegírico a Teodósio feito pelo retor Pacato, se faz menção aos povos que vivem separados "do nosso mundo" e, todavia, temem diante da potência imperial, distinguindo, então, o território sob o domínio romano da área externa na qual a superioridade militar romana é reconhecida e temida. Dessa forma, há mais referência à universalidade da hegemonia romana - ao menos da tendência de tal hegemonia, do que do domínio direto ${ }^{27}$. No panegírico a Constâncio Cloro são honrados os benefícios dos tetrarcas "distribuídos em toda a terra" (PANEGYRICUS, VIII 4, 3), mas depois é exposta a tutela exercida pelos imperadores sobre o "seu mundo", deixando entrever a permutabilidade das duas expressões (PANEGYRICUS, VIII 3, 2).

Uma situação semelhante é encontrada na literatura historiográfica da Antiguidade Tardia, até certo ponto e de maneiras diferentes em determinados autores. Aurélio Vitor utiliza prevalentemente o término "mundo romano" para designar o âmbito geográfico em que é exercitado o poder imperial ${ }^{28}$, o âmbito geográfico danificado pelos crimes de $G^{2}$ alieno ${ }^{29}$, ou arruinado pela má administração da gestão pública ${ }^{30}$. Há um único caso em que o historiador emprega "órbita terrestre" para designar o palco da crueldade de Calígula, e

\footnotetext{
${ }^{26}$ A literatura panegírica constitui-se de escritos laudatórios dirigidos a determinada pessoa, geralmente pertencente à esfera política.

${ }^{27}$ Paneg. XII, 22, 2: non haec tantum gentes tremunt quas ab orbe nostro silvarum intervalla vel flumina montesque distinguunt.

${ }^{28}$ Aur. Vict. Caes. XLI 2: Ita potestas orbis Romani duobus quaesita, qui quamvis per Flavii sororem nuptam Licinio conexi inter se erant, ob diversos mores tamen anxie triennium conmmgruere quivere.

${ }_{29}$ Aur. Vict. Caes. XXXIII 33: Et patres quidem praeter commune Romani malum orbis stimulabat proprii ordinis contumelia...

${ }^{30}$ Aur. Vict. Caes. XIII 6: Quod equidem munus satis utile in pestem orbis Romani vertit posteriorum avaritia insolentia que, nisi quod his annis suffectae vires Illyrico sunt praefecto medente Anatolio.
} 
pode-se pensar que o exagero da perspectiva constitui um engrandecimento retórico dessa referência à maldade do tirano ${ }^{31}$.

Amiano Marcelino utiliza expressões universalistas quando menciona a fase de formação do Império Romano: Roma, unindo a sua juventude e maturidade, alcançou vitórias "em muitas regiões que o vasto globo possui". Todavia, o historiador não afirma que Roma estendeu o seu domínio sobre todo o mundo. Na narrativa da história contemporânea, Amiano aplica a terminologia "mundo romano" para aumentar o poder do imperador Valentiniano I (AMMIANUS, XXIX 5, 46), com exceção da citação que o autor faz de Teodósio sênior quando este fala diante de Firmo. A referência ao poder universal do imperador poderia ser uma empreitada retórica atribuída a Teodósio para intimidar o rebelde e provocar sua sujeição. $\mathrm{Na}$ obra do historiador antioqueno existem dois passos relevantes para compreender a sua atitude diante do uso de uma terminologia universalista para definir o poder imperial, que talvez possam ser considerados uma chave para interpretar a posição sobre as pretensões universais da ideologia imperial dos historiadores latinos contemporâneos.

No primeiro desses passos, os cortesãos de Constâncio II demonstram sua preocupação com a segurança do imperador, afirmando que o estado do mundo depende da sua salvação ${ }^{32}$. Também nesse caso a ênfase na estreitíssima relação entre a vida do imperador e a situação do mundo inteiro é para Amiano uma amplificação interessada por parte dos cortesãos, com a finalidade, em tal caso, de adular o imperador, justificando e até mesmo estimulando as suas reações a qualquer possível ultraje ao seu poder. A ênfase do domínio universal do imperador não é apenas falsa em si, mas é expressão de uma ideologia autocrática que prospera no contexto da corte. Na segunda etapa, Amiano repreende em Constâncio a falta de "civilidade" porque, além de falar de si

${ }^{31}$ Aur. Vict. Caes. III 9: et repente caesis primum vario facinore innocentium paucioribus tamquam beluae hausto sanguine ingenium exercuit; itaque deinceps triennium consumptum, cum senatus atque optimi cuiusque multiplici clade terrarum orbis foedaretur.

32 Amm. XIV 5, 4: Accedebant enim eius asperitati, ubi imminuta esse amplitudo imperii dicebatur, et iracundiae suspicionum que uanitati proximorum cruentae blanditiae exaggerantium incidentia et dolere impendio simulantium, si principis periclitetur uita, a cuius salute uelut filo pendere statum orbis terrarum fictis uocibus exclamabant. 
mesmo como "minha eternidade", ditando ou escrevendo de próprio punho, define a si próprio como "senhor do mundo inteiro", enquanto deveria ter-se indignado inclusive se outros o definissem desta forma, já que aspirava conformar-se ao modelo de "governante civilizado",33. Constâncio aplica à sua pessoa um valor como a "eternidade", que pertence a Roma, e se autoproclama senhor do mundo usurpando um título que ainda diz respeito a Roma e ao povo romano.

Para Amiano, a afirmação da universalidade de um poder imperial absoluto é, pois, uma adulação cortesã que deveria ser refutada por um imperador que almejasse inspirar a concessão de poder desse grupo à tradição da civilidade, ainda mais quando esta afirmação fosse internalizada pelo próprio imperador, obscurecendo seu senso de limite. Em relação ao testemunho da titulação imperial que citamos acima, esse apelo à civilidade e à moderação dos imperadores a um poder universal aparece isolado quanto à frequência, nas inscrições dedicadas a eles, do uso de expressões universalistas, mesmo no que se refere ao poder de governantes como Juliano, o qual é apresentado por Amiano em vários aspectos como uma figura ideal de "governante civilizado" 34 .

É interessante a posição de Eutrópio sobre a universalidade do domínio romano. O Império Romano desde muito cedo cresceu por todo o mundo e atingiu dimensões tais que nenhum outro império na memória humana havia conseguido. O Império Romano era, então, o maior entre os impérios da história mundial, mas o historiador não afirma que ele dominava o mundo $\operatorname{todo}^{35}$. Essa universalidade teria sido efetivamente possível no momento do

\footnotetext{
${ }^{33} \mathrm{Amm} . \mathrm{XV} 1,3$ : quo ille studio blanditiarum exquisito sublatus immunem que se deinde fore ab omni mortalitatis incommodo fidenter existimans confestim a iustitia declinauit ita intemperanter, ut "Aeternitatem meam" aliquotiens subsereret ipse dictando scribendo que propria manu orbis totius se dominum appellaret; quod dicentibus aliis indignanter admodum ferre deberet is, qui ad aemulationem ciuilium principum formare uitam mores que suos, ut praedicabat, diligentia laborabat enixa.

${ }^{34}$ CIL III 7088=ILS 751 di Pergamo; CIL III 247=ILS 754 di Ancyra; CIL V 8061 di Ticinum; CIL XI 6639 di Forum Popilii; CIL XI 6649b di Mutina. Cfr. Mastino 1983, 113-114.

${ }^{35}$ Eutr. I 1, 1: Romanum imperium, quo neque ab exordio ullum fere minus neque incrementis toto orbe amplius humana potest memoria recordari, a Romulo exordium habet, qui Reae Silviae, Vestalis virginis, filius et, quantum putatus est, Martis cum Remo fratre uno partu editus est.
} 
conflito civil entre César e Pompeu, se os comandantes e tropas envolvidos na disputa tivessem lutado contra os bárbaros, "toda a terra teria sido facilmente subjugada" ${ }^{36}$.

$\mathrm{O}$ autor anônimo da pequena obra geralmente conhecida como Epitome de Caesaribus, escrita no fim do século IV ou no início do $\mathrm{V}$, apresenta, tal como Amiano Marcelino, um uso cronologicamente articulado das expressões "mundo terrestre" e "mundo romano". No Alto Império, para imperadores como Vespasiano, Tito e Antonino Pio, o poder imperial é apresentado como concernente ao "mundo terrestre" $"$. Em seguida, para os imperadores Aureliano, Diocleciano, Constantino II, Constante e Constâncio, o domínio imperial é definido como "mundo romano",38.

Mais complexa é a questão do uso das expressões "mundo romano" e "mundo terrestre", ou simplesmente "mundo", na História Augusta e em obras de outros gêneros literários, como em narrativas históricas, discursos e epístolas, além da presença nas próprias fontes. A diferença essencial entre as duas expressões é que a terminologia "mundo romano" diz respeito à relação entre o poder imperial e a sua extensão territorial, enquanto "mundo terrestre" é utilizada em contextos claramente celebrativos. O imperador Aureliano, escrevendo a Zenóbia, define a si mesmo como "imperador do mundo romano" (HISTORIAE AUGUSTAE, XXVI 6). Na parte narrativa da mesma Vida de Aureliano, o autor observa que após a morte do imperador o poder imperial permanece vago por seis meses (HISTORIAE AUGUSTAE, XL 4). Depois da eleição de Tácito, o Senado romano, escrevendo à cúria cartaginesa, regozijouse por lhe ter sido restituído o direito de nomear o imperador (HISTORIAE AUGUSTAE, XVIII 2). Na Vida dos dois Valerianos, o rei dos cadúsios escreve uma carta, obviamente inventada, ao rei persa Sapor convidando-o a fazer regressar Valeriano, feito prisioneiro, com a consideração de que tinha como suporte não apenas o filho imperador e o sobrinho César, mas todo o

\footnotetext{
${ }^{36}$ Eutr. VI 21, 1: Numquam adhuc Romanae copiae in unum neque maiores neque melioribus ducibus convenerant, totum terrarum orbem facile subacturae, si contra barbaros ducerentur.

${ }^{37}$ Epit. IX 5 (Vespasiano); X 16 (Tito); XV 2 (Antonino Pio).

${ }^{38}$ Epit. XXXV 2 (Aureliano); XXXIX 1 (Diocleciano); XLI 19 (Constantino II, Constante, Constâncio II); XLIII 1 (Juliano).
} 
Império Romano (HISTORIAE AUGUSTAE, II 2). "Mundo romano" é também empregado para definir a lealdade e a relação de amor das instituições e das províncias romanas para com seu imperador, como no caso das considerações atribuídas a Filipe, o Árabe no momento de ordenar o assassinato de Gordiano III (HISTORIAE AUGUSTAE, XXX 8).

No mesmo contexto de designação do título imperial em relação ao território sobre o qual se exercita o poder, a escolha de uma ênfase retórica conduz à utilização de "mundo terrestre". Na carta de agradecimento solene de Probo ao Senado, por tê-lo eleito imperador, a relação Senado-imperador é totalmente expressa em términos universalistas: os senadores, que são "governantes do mundo", haviam dado ao mundo um príncipe (HISTORIAE AUGUSTAE, XI 1) ${ }^{39}$. Assim, quando quer exaltar o alcance e as consequências de uma escolha política imperial, o autor da Historia Augusta usa a expressão "mundo terrestre". O imperador Septímio Severo, decretando o esquecimento da memória de Plauciano, manda demolir as estátuas por toda a terra, o que ocorre apenas em território imperial (HISTORIAE AUGUSTAE, XIV 4) ${ }^{40}$. A paz pela qual Adriano luta é uma paz universal (HISTORIAE AUGUSTAE, V 1), mas também o ódio difundido contra Maximino Trácio é apresentado de forma enfática como um ódio de todo o mundo ${ }^{41}$.

O historiador cristão Orósio possui uma posição específica quanto ao universalismo do Império Romano (SARDELLA, 2015). Na descrição das três partes do mundo no início da sua História, Orósio não pode deixar de notar, à par da descrição das províncias romanas, a presença de extensos territórios na Ásia que não pertencem ao Império - sem, contudo, explicitar essa ideia, como no caso de Estrabão que citamos - a Índia, a ilha de Taprobane e os territórios, do Rio Indo ao Tigre, que fazem parte de Parta e que ao seu tempo pertenceram

\footnotetext{
${ }^{39}$ Em uma menção do governo do mesmo Probo, na Vita Taciti, a pacatio imperii é apresentada como uma pacatio universal (Tac. XVI 6: omnium iudicio bonorum imperator est factus orbemque terrarum pacatissimum gubernavit).

${ }^{40}$ Exaltando a intenção atribuída a Probo de uma renúncia ao exército (brevi milites necessarios non habebimus, o autor da Historia Augusta imagina o mundo inteiro sem armas (Prob. XX 5: orbis terrarum non arma fabricabitur), enquanto pouco depois comemora a atividade militar do mesmo imperador per totum orbem terrarum (Prob. XXII 2).

${ }^{41}$ Hist. Aug. Gord. VII 3: cum iam orbis terrarum odio contra Maximinum arderet.
} 
ao Império persa. O Império de Alexandre é definido, entretanto, como um império universal: o macedônio com um exército pequeno conquista todo o mundo (OROSIUS, III 16, 3), embora o historiador se pergunte se a virtude que o move à conquista do mundo deve ser elogiada ou se é preciso lamentar a miséria e a desolação imposta ao mundo conquistado ${ }^{42}$.

Contudo, se o Império de Alexandre é um império especialmente asiático e se estende a partes muito limitadas da África e da Europa, Orósio evidencia que é precisamente dessas partes do mundo que os embaixadores dos povos e cidades impressionados pela sua potência chegam à Babilônia, e que, então, reconhecem a sua supremacia, desde Cartago e de todas as cidades africanas, desde a Espanha e Gália, da Sicília, Sardenha e da maior parte da Itália - mas não de Roma (OROSIUS, 20, 2). Mesmo na situação contrária é possível estabelecer um paralelo em relação a Alexandre: embaixadores orientais, indianos e citas se dirigem a César, senhor do Ocidente (OROSIUS, VI 21, 19; Conferir SORDI, 1990). Como vimos nas Res gestae de Augusto, a universalidade do Império não se manifesta apenas no domínio territorial, mas também no reconhecimento universal da hegemonia. Uma ênfase particular, finalmente, é dedicada por Orósio à universalidade do Império de Augusto, especialmente à universalidade da "Paz Augusta", já que constitui o contexto providencial do nascimento de Cristo (OROSIUS, III 8, 5).

Também o cristianismo, como é sabido, pretende ser uma religião universal: nos textos neotestamentários - em que, como no Evangelho de Mateus, coexistem particularismo hebraico (RUNESSON, 2000) e universalismo da missão salvífica de Cristo (CUVILLIER, 1997; INGELAERE, 1995; TISERA, 1993) -, nos escritos paulinos (BADIOU BRASSIER, 2003) e nos textos veterotestamentários interpretados segundo a visão cristã, é anunciada a pregação da palavra de Cristo a todos os povos até aos limites do mundo conhecido (ROBINSON, 2000). A religião une cidades e povos em um novo povo, o cristão, restabelecendo, como afirma Orígenes, a

\footnotetext{
${ }^{42}$ Oros. hist.III 20, 10: at vero si illa Alexandri tempora laudanda propter virtutem qua totus orbis obtentus quam detestada propter ruinam qua totus orbis eversus est iudicantur...
} 
originária unidade da humanidade (BUELL, 2002). Inicialmente essa pregação universal foi concebida dentro dos limites do Império Romano; a partir de Orígenes, o momento do nascimento de Cristo e da criação do Império de Augusto foi considerado o contexto ideal preparado pela providência divina para a difusão da religião cristã (ORÍGENES, II 30).

O próprio Orígenes, porém, observa que o Evangelho do Reino não havia ainda sido pregado em toda a Terra, em um contexto no qual são mencionadas as missões cristãs para além das fronteiras do Império. No comentário a Gênesis do pai alexandrino (ORÍGENES, PG XII 92), como mais tarde na História Eclesiástica de Eusébio de Cesareia (EUSEBIUS, III 1, 1), é mencionada a missão do apóstolo Tomás em Parta e a do apóstolo André na Cítia. Eusébio recorda a pregação do apóstolo Filipe ao dignitário da rainha da Etiópia, por meio de quem o Evangelho foi espalhado na sua terra (EUSEBIUS, II 1, 13).

Na Demonstratio evangelica de Eusébio, o elenco dos povos bárbaros alcançados pela palavra de Cristo é ainda mais amplo: persas, armênios, partos, citas e britânicos (EUSEBIUS, III 4, 45; Conferir SIMMONS, 2010). O anúncio da palavra aos bárbaros produz mudanças de costumes: os persas não se casam mais com as próprias mães, os citas não praticam mais o canibalismo, nem outros povos bárbaros se unem às próprias filhas e às próprias irmãs. $\mathrm{O}$ cristianismo converte os bárbaros à razão e à filosofia, mesmo os mais selvagens, e nessa extraordinária capacidade de persuasão manifesta-se a sua superioridade em relação à cultura grega (NERI, 2010).

Particularmente no império cristão, a partir de Eusébio de Cesareia, há confiança no pleno cumprimento da profecia sobre a difusão da religião cristã entre todos os povos $^{43}$. A questão dos limites da difusão do cristianismo ocupa um espaço relevante apenas na obra de Agostinho, no que diz respeito à crítica por parte dos donatistas ao conceito da igreja católica enquanto universalmente difundida. Na epístola 93, o bispo de Hipona responde ao bispo donatista

\footnotetext{
${ }^{43}$ Cfr. por exemplo Zen. Veron., Tract. I 34: erat enim futurum ut omnium nationum in Christo credentibus populis totus orbis Deo una civitas redderetur.
} 
Vincenzo de Cartena, que havia dito: "em relação a todas as partes do mundo, aquela em que a fé cristã é conhecida é bem pequena em comparação com o mundo inteiro" (AUGUSTINUS, XCIII 7, 22). A rapidez da conversão recente de muitos povos bárbaros, afirma Agostinho, torna evidente a todos, também aos inimigos de Cristo, que as profecias sobre a difusão universal do cristianismo serão cumpridas em curto espaço de tempo (AUGUSTINUS, XCIII 7, 22). O bispo afirma na epístola 197 que, se não no tempo da nossa vida, ao menos dos jovens destinados a alcançar a velhice (AUGUSTINUS, CXCVII 4).

Na epístola 199, escrita ao bispo Hesíquio, o qual, em relação à vinda de Cristo - quando a palavra terá sido pregada a todos os povos -, havia afirmado que a evangelização universal já tinha sido anunciada com os apóstolos, Agostinho parece apresentar uma visão menos otimista e mais realista sobre a difusão do Evangelho no presente, partindo do reconhecimento da realidade africana: "aqui na África há inúmeras tribos de bárbaros aos quais o Evangelho não foi pregado ainda, como é fácil informar-se pelos prisioneiros que chegaram a nossa cidade, e aumentam em número os escravos dos romanos. A Parúsia que se cumprirá quando o Evangelho for anunciado a todos os povos ainda não está iminente porque a igreja tem a possibilidade de crescer 'até que se cumpra a profecia que fala de Cristo feita por Salomão, sua prefiguração: Reinará de um mar ao outro e do rio até à extremidade da terra"” (AUGUSTINUS, CXCIX 12). Além desse testemunho de Agostinho, não temos outros que demonstrem da parte cristã a consciência dos limites da evangelização universal, mas temos informações triunfantes da efetiva difusão universal no presente da igreja a partir de Lactâncio ${ }^{44}$. Na época justiniana, Cosme Indicopleustes cita a presença da igreja cristã até a extremidade do mundo: a ilha de Taprobane na Índia, a Bactriana, e o reino persa no Oriente, a Etiópia, a Núbia e o país dos garamantes, ao sul, as terras hiperbóreas dos

\footnotetext{
${ }^{44}$ Lact. inst. VII, 15, 5: nunc autem quia populus Dei ex omnibus linguis congregatus apud omnes gentes commoratur.
} 
hircanos e os citas ao norte (COSM. IND. TOPOGR. III 64-66; Conferir LEVILLAYER 2008).

Esse conhecimento da proximidade da difusão efetiva universal do cristianismo tem relação, nos autores cristãos, com a ideologia universalista do Império. Apresentaremos, então, alguns casos. Na Vita Constantini, Eusébio de Cesareia comemora as empreitadas expansionistas do governante em relação a todas as direções do Império, aproximando-se dos limites do mundo conhecido. Eusébio desenvolve um contraponto entre Constantino e Alexandre, o Grande, afirmando que não apenas o reino do primeiro foi muito mais longo, mas também que, diferente do reino macedônico, o reino constantiniano se estendeu em todas as direções para além das fronteiras imperiais - das terras banhadas pelo Oceano ocidental, aos etíopes e aos indianos (EUSEBIUS, 1, 8, 4); não através da conquista, mas por meio do reconhecimento da sua autoridade. Ele mesmo conta que havia sido testemunha da presença na corte de embaixadores de diversos povos bárbaros que foram oferecer homenagem ao imperador blêmios, etíopes e indianos - personagens muito diferentes em aparência e vestuário, mas caracterizados por uma impressionante alteridade de corpos gigantescos e aparência terrível (EUSEBIUS, 4, 7, 1).

Universalismo imperial e universalismo cristão se fundem no discurso para a comemoração dos trinta anos de governo do imperador (EUSEBIUS, 16, 6): se os ensinamentos de Cristo se dirigem a toda a humanidade até aos limites do mundo, também o Império Romano, que sob Augusto havia reunido grande parte dos povos, é destinado a expandir-se até aos limites da terra, facilitado pela difusão do cristianismo. Ou seja, não é a expansão universal do Império que favorece a expansão do cristianismo, mas é a difusão do cristianismo que cria as condições para a ampliação do Império. As profecias do Velho Testamento de um reino universal e de um mundo pacífico contidas no Salmo 72 e em Isaías 2.4 são declaradas cumpridas no tempo presente.

Rufino de Aquileia, que escreve em latim uma História Eclesiástica no início do século $\mathrm{V}$, coloca sob o reino de Constantino a conversão dos ibéricos do Ponto (uma parte da atual Geórgia) (RUFINUS, I 11). Uma embaixada foi 
mais tarde enviada a Constantino, que, ao saber sobre a conversão, se regozijou mais do que se tivesse unido ao Império Romano nações desconhecidas. A cristianização neste caso suplanta a conquista e permite a entrada da Geórgia na zona de influência do Império (LEVILLAYER, 2008, 231; THÉLAMON, 1972). Na época de Constantino, Rufino aponta também a conversão de um povo indiano, na qual, contudo, o imperador não estava envolvido.

A celebração feita por Eusébio sobre o encontro das duas universalidades não é completamente compartilhada por personagens importantes da cristandade que o sucederam. Ambrósio, dirigindo-se a imperadores cristãos, demonstra partilhar da ideologia universalista expressa na titulação. Voltandose a Graciano no escrito Sobre a fé, o autor o define como imperador "de todo o mundo" (AMBROSIUS, I, pr). Na obra Sobre a morte de Teodósio, o cravo da cruz verdadeira, que encontra na coroa imperial, "reina sobre o mundo inteiro" (AMBROSIUS, XLVIII). Na origem da igreja, o Império de Augusto estende o seu poder a "todo o mundo" (AMBROSIUS, XLV 21, 3). Contudo, no comentário ao Evangelho de Lucas, Ambrósio afirma que o domínio do mundo era de Cristo, não de Augusto, pois não estavam em seu poder os godos e os armênios (AMBROSIUS, II 1, 517), os quais, mesmo em seu tempo, não estavam submetidos ao Império, mas eram cristianizados - os godos pelo menos em parte.

O cristianismo, poderia sugerir o bispo de Milão, está e estava ao menos mais próximo a um universalismo real do que o Império Romano. No entanto, o episódio da conversão da rainha dos marcomanos, Fritigil, narrado pelo seu biógrafo Paulino, testemunha a conjunção no pensamento do bispo milanês sobre a conversão ao cristianismo e à romanização: a rainha, instada por Ambrósio, com quem entrara em contato epistolar, convence o marido a se submeter à autoridade romana (PAULINUS, XXXVI).

Agostinho apresenta uma posição de maior destaque da ideologia universalista imperial principalmente depois de 410. No Sermão 105, escrito provavelmente nos anos 410/411, o bispo de Hipona critica abertamente essa ideologia destacando a falsidade da profecia declarada por Júpiter, segundo 
Virgílio, a respeito de um Império sem fim. O próprio Virgílio admite: "Eu também sei, mas que coisa eu deveria ter feito, vendendo palavras aos romanos, se não prometesse, com esta adulação, algo que era falso? (AUGUSTINUS, CV 10). Como vimos, o bispo de Hipona celebra a aceleração no seu tempo do cumprimento das profecias sobre a difusão universal do cristianismo. No Sermão 113 ele lembra ao povo cristão: “de fato, irmãos, nós mesmos, não apenas nós cristãos que estamos aqui, mas que estamos agora em todo o mundo. Não o éramos alguns anos atrás; e é um milagre o fato de que o que não erámos por tantos séculos, somos, no entanto, agora" (AUGUSTINUS, CXIII). No comentário ao Salmo 95, escrito provavelmente em 412, o bispo de Hipona compara o dinamismo superior da igreja, que está convertendo muitos bárbaros de além das fronteiras do Império, com a capacidade expansiva deste: "regiões onde o Império ainda não se estende, Cristo as possui, o que está até agora fechado aos que combatem com ferro, não está àqueles que combatem com a madeira" (AUGUSTINUS, 95, 2). Essa expansão do cristianismo para além dos limites do Império, no pensamento de Agostinho, seguirá também no futuro envolvendo cada vez mais extensamente os bárbaros ${ }^{45}$.

A promessa feita por Deus a Abraão e à sua descendência não diz respeito apenas aos romanos, afirma ainda Agostinho, mas a todos os povos, como demonstra o fato de que o Evangelho é difundido também entre povos que não estão sujeitos ao domínio romano (AUGUSTINUS, 199, 12, 47). O bispo reconhece que o Império Romano anulou as diferenças étnicas no seu interior e não se baseou no predomínio de uma etnia, como afirma no Sermão 351: “todos os cidadãos romanos possuem o reino romano, mesmo que nem todos comandem, mas alguns obedeçam a outros que são os líderes" (AUGUSTINUS, 351, PL 39, 1544). Essa afirmação da integração dos povos no Império não se estende, contudo, à perspectiva futura de um mundo concomitantemente romanizado e cristianizado.

\footnotetext{
45 Aug., contra Cresc., 4, 61, 74: ad multas etiam barbaras gentes extra orbem Romanum crescendo perventura est (sc. Ecclesia).
} 
É pertinente concluir apontando para um outro texto que testemunha o desprendimento da igreja ocidental do universalismo imperial romano, um sermão de Leão Magno, escrito em meados do século $\mathrm{V}$, no qual a centralidade da Roma cristã no universo cristão foi substituída pela centralidade da cidade no universo romano: Roma é a cabeça do mundo como sede de Pedro e tem um poder maior neste plano do que tinha no plano político e militar, "por mais que muitas vitórias - afirma o papa voltando-se para Roma - vocês estenderam o Império por terra e mar, todavia o que vos subjugou ao esforço de guerra é menos do que o que vos sujeitou à paz cristã ${ }^{~} 46$.

Diferentemente, por questões políticas óbvias, é a situação na parte oriental do Império em que, particularmente sob Justiniano, a cristianização dos povos de além das fronteiras é geralmente ligada à sua atração na órbita imperial romana. Um exemplo é a situação de Lázica, um reino que se estendia até a parte ocidental da atual Geórgia. Já sob o reino de Justino I, o predecessor de Justiniano, os lazes haviam se convertido ao cristianismo. Devido a essa escolha religiosa, o rei Tzah recusou a proteção persa e foi batizado em Constantinopla, além de ter recebido a investidura do imperador Justino I, impulsionado por seu sobrinho Justiniano, fazendo, assim, do seu governo um governo satélite do Império. Um caso similar é o da cristianização dos nobades, um povo da Baixa Núbia sob Justiniano, protegido pelo Império contra os seus rivais blêmios e cuja igreja foi vinculada ao episcopado egípcio de Philae (LEVILLAYER, 2008, 234-235; Conferir MARAVAL, 2016).

\footnotetext{
${ }^{46}$ Leo Magn., serm. 82: Isti sunt sancti patres tui ueri que pastores, qui te regnis caelestibus inserendam multo melius multo que felicius quam illi discordes usque ad parricidium gemini condiderunt, ut gens sancta, populus electus, ciuitas sacerdotalis et regia, per sacram beati Petri sedem caput totius orbis effecta, latius praesideres religione diuina quam dominatione terrena. Quamuis enim multis aucta uictoriis ius imperii tui terra mari que distenderes, minus tamen est quod tibi belliczius labor subdidit quam quod pax christiana subiecit.
} 


\section{Referências}

ARNAUD. Texte et carte de Marcus Agrippa: historiographie et données textuelles. Geographia antiqua, XVI-XVII, 73-126, 2007-2008.

BADIOU; BRASSIER. 2003: Saint Paul: the foundation of universalism. Stanford, 2003.

BARONOWSKI. Polybius and Roman imperialism. London, 2011.

BIANCHETTI. Disegnare e dominare la terra: conoscenza geografca e rappresentazione dell'ecumene nella tradizione greco-romana, in Serta antiqua et medievalia 14: il signifcato delle immagini: numismatica, arte, flologia, storia. Atti del secondo incontro internazionale di studio del Lexicon Iconographicum Numismaticae (Genova 10-12 novembre 2005, Roma, 6989), 2012.

BORM. Das Königtum der Sasaniden. Strukturen und Probleme. Bemerkungen aus althistorischen Sicht. Klio, XC, 423-443, 2008.

BOSBACH. Monarchia universalis: storia di un concetto cardine della politica europea (secoli 16-18). Milano, 1998.

BRUNT. Roman imperial illusions. Roman imperial themes. Edited by Brunt, Oxford, 466-, 1990.

BUELL. Race and universalism in early Christianity. JECS, X, 429-468, 2002.

CAMPBELL. Universality and particularity in Paul's understanding and strategy of mission. Paul as missionary: identity, activity, theology and practice. Edited by Burke; Rosner, New York-London, 195-208, 2011.

CHIAI. Jenseits der Oikoumene: literarische Darstellungen des Nordens von der archaischen bis zur frühen Kaiserzeit. OTerr, XIII, 42-70, 2015.

CRESCI MARRONE. Ecumene augustea: una politca per il consenso. Roma, 1993.

CUVILLIER. Particularisme et universalisme chez Matthieu: quelaues hypothèses à l'épreuve du texte. Biblica, LXXVIII, 481-502, 1997.

GASLAIN; MALEUVRE. Auguste et les Arsacides ou le prix des enseignes. Parthica, VIII, 169-194, 2006.

GIARDINA. Cassiodoro politico. Roma, 2006. 
GREGORI; FILIPPINI. L'epigrafa costantiniana. La figura di Costantino e la propaganda imperiale. Enciclopedia costantiniana, 2013.

HARTMANN. Das Bild der Parther bei Plutarch, Historia, LVII, 426-452, 2008.

HUYSE. Die sasanidische Königstitulatur. Eine Gegenüberstellung der Quellen. Eran und Anera, Stuttgart, 2006.

INGELAER. Universalisme et particularisme dans l'évangile de Matthieu: Matthieu et le judaisme. RHPhR, LXXV, 45-59, 1995.

KÜHNEN. Die Imitatio Alexandri in der römischen Politik (1.Jh.v.Chr.-3. Jh.n.Chr. Münster, 2008.

LEROUGE. L'image des Parthes dans le monde gréco-romain: du début du Ier siècle av. J.-C. jusqu'à la fn du Haut Empire romain. Stuttgart, 2007.

LEROUGE. Comment se construit une image des Parthes à Rome. Identités romaines: conscience de soi et représentations de l'autre dans la Rome antique, Edited by Simon, Paris, 147-156, 2011.

LEVILLAYER. Quelques réflexions sur l'universalisme romano-byzantin (IVVII siècle). Hypothèses, XI, 232-233, 2008.

MARAVAL. Justinien, le reve d'un empire chrétien universel. Paris, 2016.

MASTINO. Orbis, kosmos, oikoumene: aspetti spaziali dell'idea di impero universale da Augusto a Teodosio. Napoli, 1983.

MCDONOUGH. Were the Sasanians barbarians? Roman writers on the empire of the Persians, in Romans, barbarians and the transformation of the Roman world: cultural interaction and the creation of identity in late antiquity. Edited by Mathisen; Shanzen, Ashgate, 55-65, 2011.

MEHL. Imperium sine fne dedi: die augusteische Vorstellung von der Grenzenlosigkeit des Römischen Reiches. Stuttgarter Kolloquium zur historischen Geographie des Altertums, 4, 1990, Amsterdam, 431-464, 1994.

MUSTI. Polibio e l’imperialismo romano. Napoli, 1978.

NERI. Romani, Greci e barbari. Identità etniche e universalismi nell'opera di Eusebio di Cesarea. Adamantius, XVI, 2010.

NICOLET. Space, geography and politics in the early Roman empire. Ann Arbor, 1991. 
PAVAN. Imperium sine fne dedi (Aen. I, 279). L'infnito dei Greci e dei

Romani, Genova, 107-120, 1989.

POGORZELSKI. Orbis Romanus: Lucan and the limits of the Roman world.

TAPhA, CXLI, 2011.

PRONTERA. Le Porte Caspie: dalla topografa alla geografa, in II paesaggio e l'esperienza. Scritti di antichità offerti a Pierluigi Tozzi in occasione del suo 75 compleanno, a cura di Bargnesi; Scuderi, Pavia, 129-134, 2012.

ROBINSON. Te compassionate God of all nations: intimations of universalism in the Old Testament. Scripture Bulletin, XXX, 23-33, 2000.

RODDAZ. Auguste et les confns, in L'Africa romana. Ai confni dell'impero: contratti, scambi, conflitti. Atti del XV convegno di studio, Tozeur, 11-15 dicembre 2002, Roma, I, 261-276, 2004.

RUNESSON. Particularistic Judaism and universalistic christianity? Some critical remarks onterminology and theology. Journal of Graeco-Roman christianity and Judaism, I, 120-134, 2000.

SARDELLA. Identità e universalismo: il cristianesimo come passaporto di romanità nella tarda antichità (Orosio, Le Storie contro i pagani). Bandue, VIII, 111-126, 2015.

SIMMONS. Universalism in the Demonstratio evangelica of Eusebius of Caesarea. Studia patristica, XLVI, Edited by Baun, Cameron, Edwards, Vinzent, Leuven-Paris-Walpole, 319-324, 2010.

SLOOTJES; PEACHIN. Rome and the worlds beyond its frontiers. Leiden, 2010: SOMMER. Le ragioni della guerra: Roma, i Parti e l'ultimo imperativo di Cesare, in Cesare, precursore o visionario? Atti del convegno internazionale, Cividale del Friuli, 17-19 settembre 2009, a cura di Urso, Pisa, 123-140, 2016.

SORDI. Alessandro e Roma nella concezione storiografca di Orosio, in Neronia IV: Alejandro Magno, modelo de los emperadores romanos. Edited by Croisille; Bruxelles, 388-395, 1990.

THÉLAMON. Histoire et structure mytique: la conversione des Ibères. RH, XCVI, 5-28, 1972.

TISERA. Universalism according to the Gospel of Matthew. Bern 1993.

VOGT. Orbis Romanus. Ein Beitrag zum Sprachgebrauch und zur Vorstellungswelt des römischen Imperialismus, ripubblicato. Orbis. 
Ausgewählte Schriften zur Geschichte des Altertums, Freiburg-Basel-Wien, 151-171, 1960.

WELLS. Rome beyond its frontiers: imports attitudes and practices. JRA, XCIV, 2013.

WHITTAKER. Le commerce romain avec l'Inde et a prise de décision économique. Topoi (Lyon), X, 268, 2000.

WIESENHÖFER. Augustus und die Parther. "Imperium". Varus und seine Zeit. Beiträge zum internationalen Colloquium des $L W L$-Römermuseum am 28. und 29. April 2008 in Münster, Münster, 187-196, 2010.

Recebido em: 11 de fevereiro de 2021

Aceito em: 14 de julho de 2021 